prevalence of prairie fires in spring and autumn. Personally I favour the latter, tnough both causes may in part be answerable. If worms abound in Iceland $\left(65^{\circ} \mathrm{N}\right.$. lat. $)$, in Kerguelen Land $\left(50^{\circ} \mathrm{S}\right.$. lat.), and in Toronto $\left(43.4^{\circ} \mathrm{N}\right.$. lat., mean winter temperature $27_{+}^{\circ} \mathrm{F}$.), why should they not also occur at Winnineg $\left(50^{\circ} \mathrm{N}\right.$. lat.)? Certairly the mean winter temperature is very low, heing about $8^{\circ} \mathrm{F}$, and the mean minimum for eleven years $-40^{10} \mathrm{~F}$. I made special inquiries as to the depth to which the soil in Manitoba becomes frozen in winter. This is ofen as much as five or six feet, but only, I believe, in the more exposed places, and certainly as a rule it is thawed again in the spring. I do not think this would render the ground uninhabitable by worms when they are able to exist in Iceland. Mr. Daru in says nothing as to the effect of frost on worms except (p. 26) that " worms are sensitive to a low temperature, as may be inferred from their not coming out of their burrows during a frost "; but he states (p. I Io) that they are easily able to descend three or four or even seven or eight feet below the surface. It would be interesting to ascertain whether worms inhabit equally cold portions of the Old World.

But the agency which I believe has caused the absence of earthworms from the North-West is, as already stated, the prairie fires which annually sweep over enormous portions of the country, totally consuming the grass, and converting it into a black ash. This, it might well be imagined, would for months together completely deprive any worms that formerly existed of that variety of decaying vegetable matter that composes their food; and assuming that fires have annually passed over large portions of the prairies for scores of generations (as seems in every way probable), it appears to me only reasonable to suppose that this cause would effectually have exterminated the worms from the country or have prevented them occupying it. It is my belief (as I shall elsewhere state more fully) that the very fertile, fine, black, powdery, and almost soot-like soil from one to three feet thick, even the open, treeless nature of the prairies themselves, and the absence from their surface, so far as my observation goes, of every single species of mollusk, while many species abound in all the ponds, lakes, and streams, are all in a large degree, if not entirely, due to the action of the fire. If this view ultimately turns out to be correct, it will be further seen that the very means which has deprived the soil of the North-West of that natural cultivation which the soils of most other countries enjoy has, at the same time, liberally supplied it with a manure resulting from the charred ashes of the grass which is annually burned. My friend, Mr. T. Rogers, who has taken much interest in the absence of worms from the North West, and is inclined to attribute it rather to frost than to fire, though he suggests that the "alkali" may possibly have had something to do with it, has already brought the subject before the Literary and Scientific Society of Manchester, where he seems to have met with a good deal of incredulity.

As another evidence of the absence of worms, the numerous, Jarge, Glacial boulders that strew the prairies around Brandon and elsewhere may be cited. These, had worms exi-ted, would doubtless have long ago been lowered beneath the surface, as also the skulls and other bones of buffaloes, which so abound on the prairies, and most of which have evidently lain there a long while. Nevertheless some of these have been buried in the course of time, as one gentleman toll me that he had sometimes turned them up from a depth of two or three inches beneath the surface when ploughing. Their burial may have been accomplished by the wind drifting soil over them, or by the working of gophers. Of these peculiar little animals two species are very abundant on the prairies, where they make extensive burrows, which it seems possible may to some extent accomplish the natural cul:ivation of the soil in the way worms are accustomed to do it elsewhere. Some more suggestive remarks on this point may be found in a paper by Mr. Seton, published in the Report of the Manitoba Department of Agriculture for 1882, and which may be studied with advantage. ROBT. Miller CHRISTy

Chignal St. James, near Chelmsford, December 20, 1883

\section{Magnetic Dip in South China and Formosa}

WHILE engaged on a meteorological mission in China I availed myself of the opportunity to make the following determinations of the magnetic dip. The observations in Hong Kong were made at the public gardens, the Observatory being not yet ready. On October ro I observed at the British Consulate ; on November 3 at the English Presbyterian Missions Ccmpound, Swatow. In Amoy I observed at the residence of the Commismissioner I.M. Customs, in Takow (Formosa) at the Custom House, and at the South Cape (Formosa), near the magnificent fortified lighthouse. It is to be feared that the observations on the coast of China are slightly vitiated from local attraction, the rocks consisting of ferruginous granite. Southern Formosa is built up of coral, raised in places to a great height, no doubt through volcanic action. Slight earthquakes are of common occurrence in Formosa, whereas along the coast of China they are rare and of no importance except to the seismologist.

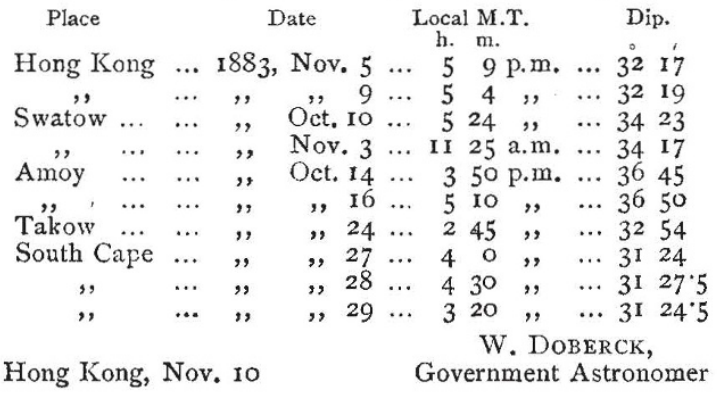

\section{THE ORIGIN OF CORAL REEFS}

REGARDING this interesting geological problem, which has recently been discussed in NATURE, we are enabled through the kindness of Mr. Murray, of the Challenger Commission, to publish a letter which has been addressed to him by Dr. Guppy from the Pacific. The importance of this communication will be recognised in the confirmation it supplies of the inference that coral reefs start upon a platform of limestone composed of the remains of foraminifera, \&c., and are themselves of no great thickness. Dr. Guppy will no doubt continue his researches, and we may hope to obtain from him precise data regarding the average thickness of the coral rock, the lithological difference between it and the underlying limestone, the structure of the limestone, whether any succession of organisms can be detected in it, and whether at any point the underlying volcanic rock can be seen which would afford a measurement of the thickness of the calcareous deposits. The effects of denudation and their relation to height above the sea will no doubt also receive his attention.

$$
\begin{gathered}
\text { "Shortlands Islands, Solomon Group, } \\
\text { "August 7, I } 883
\end{gathered}
$$

"During the twelve months I have spent in this group of islands-serving as surgeon on board H.M. surveying-ship Lark - I have been much interested in and have devoted considerable attention to the raised coral formations in various islands; and as my observations may be of service towards confirming the views which you have advanced with reference to coral islands and reefs, I will state briefly the results of my observations.

"Excluding the large continental islands, I will refer for the sake of brevity to the numerous small islands of this archipelago, those of volcanic, and those of calcareous formations. Confining myself to the islands of calcareous formation, I will pass over the numerous small islands which are entirely composed of coral detritus, sand, and shells, and have been formed by the materials thrown up by the waves at the present sea-level; and will restrict my remarks to a very common type of islands in this group, with gently sloping and rounded profile, having an elevation varying perhaps between 100 and 1100 or 1200 feet, and composed in bulk of an impure earthy or argillaceous limestone, usually bedded, and almost always foraminiferous, now and then rich in other pelagic organisms, such as Pteropods. On this rock rests the 